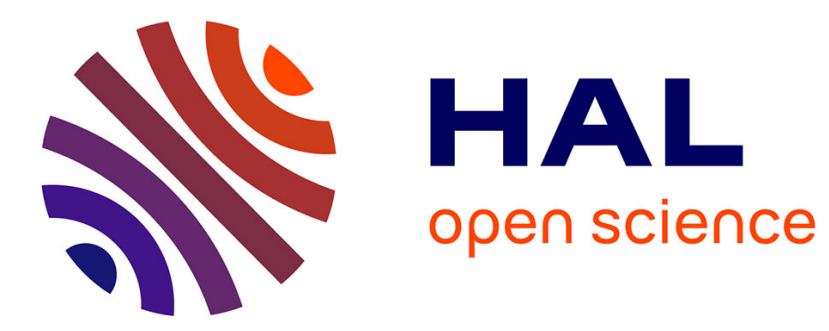

\title{
Pediatric pharmacogenetic and pharmacogenomic studies: the current state and future perspectives
}

Roberta Russo, Mario Capasso, Paolo Paolucci, Achille Iolascon

\section{To cite this version:}

Roberta Russo, Mario Capasso, Paolo Paolucci, Achille Iolascon. Pediatric pharmacogenetic and pharmacogenomic studies: the current state and future perspectives. European Journal of Clinical Pharmacology, 2010, 67 (S1), pp.17-27. 10.1007/s00228-010-0931-1 . hal-00640239

\section{HAL Id: hal-00640239 \\ https://hal.science/hal-00640239}

Submitted on 11 Nov 2011

HAL is a multi-disciplinary open access archive for the deposit and dissemination of scientific research documents, whether they are published or not. The documents may come from teaching and research institutions in France or abroad, or from public or private research centers.
L'archive ouverte pluridisciplinaire HAL, est destinée au dépôt et à la diffusion de documents scientifiques de niveau recherche, publiés ou non, émanant des établissements d'enseignement et de recherche français ou étrangers, des laboratoires publics ou privés. 
Pediatric pharmacogenetic and pharmacogenomic studies: the current state and future perspectives

Part of TEDDY Supplement

Roberta Russo $^{1}$, Mario Capasso ${ }^{1,3}$, Paolo Paolucci ${ }^{2}$, Achille Iolascon ${ }^{* 1,3}$

on behalf of the TEDDY European Network of Excellence

1- CEINGE Biotecnologie Avanzate, Napoli, Italy

2- Department of Mother and Child, University of Modena and Reggio Emilia, Modena, Italy

3- Department of Biochemistry and Medical Biotechnologies, University of Naples Federico II, Italy

SHORT TITLE:

Pharmacogenetics and pharmacogenomics in children

Roberta Russo e-mail: russor@ceinge.unina.it

Mario Capasso e-mail: capasso@ceinge.unina.it

Paolo Paolucci e-mail: paolo.paolucci@unimore.it

Achille Iolascon e-mail: iolascon@ceinge.unina.it

\section{${ }^{*}$ CORRESPONDING AUTHOR}

Iolascon Achille, MD

Full Professor of Medical Genetics. Department of Biochemistry and Medical Biotechnologies, University Federico II of Naples; CEINGE Biotecnologie Avanzate, Via Comunale Margherita 482, 80145-Napoli.

Tel. +390813737897

Fax +390813737804

iolascon@,ceinge.unina.it 


\begin{abstract}
Genetic differences between individuals can explain some of the variability observed during drug treatment. Many studies have correlated the different pharmacological response to genetic variability, but most of them have been conducted on adult populations. Much less attention has been given to pediatric population. Pediatric patients constitute a vulnerable group with regard to rational drug prescribing since they present differences arising from the various stage of development. However, only few steps have been made in developmental pharmacogenomics. This review attempts to describe the current methods for pharmacogenetic and pharmacogenomic studies, providing some of the most studied examples in pediatric patients. It also gives an overview on the implication and importance of microRNA polymorphisms, transcriptomics, metabonomics and proteomics in pharmacogenetics and pharmacogenomics studies.
\end{abstract}

Keywords: pharmacogenetics, pharmacogenomics, GWAS, transcriptomics, metabonomics, proteomics 


\section{Introduction}

After more than 50 years of pharmacogenetics (PGt) and pharmacogenomics (PGx) research, we have learned that genetic differences between individuals can explain some of the variability observed in the pharmacokinetics, efficacy and toxicity of some drugs. Indeed, the magnitude of variation in the pharmacokinetics of a drug caused by genetic variants often far exceeds the range considered as acceptable when comparing the bioavailability of two different drug formulations [1]. Furthermore, there is evidence that consideration of PGt when prescribing drugs could significantly improve the safety and efficacy of therapy $[2,3]$.

The term pharmacogenomics refers to the investigation of variations of DNA and RNA characteristics as related to drug response, while pharmacogenetics is a subset of PGx and defined as the influence of variations in DNA sequence on drug response [4]. An increasing number of examples describing differences in drug response as a result of genetic polymorphisms and gene expression have been published, but most of these reports include only adult individuals. Few studies deal with PGx of children and highlight the most important difference between children and adults. This review seeks to describe the main biological differences in drug metabolizing capabilities between children and adults, to give an overview on the rapidly evolving research fields of both PGt and PGx, and also to illustrate what impact these studies can have on the development of personalized medicine in pediatric patients.

\section{Response to the drugs: what is the difference between children and adults?}

Human development, from the prenatal period through to adolescence, is a dynamic process. Newborns and infants rapidly undergo simultaneous stages of organ growth and demonstrate large variability in drug response and metabolizing capabilities [5]. Drugs may have different actions on individuals, not only within the adult population but also in children, because of genetic polymorphisms. There are several demonstrations of acute adverse effects (ADR) of drugs, even fatal, due to the presence of genetic variations in drug metabolism that alters the levels of active drugs and metabolites. One frequently cited example is the morphine poisoning in a breastfed neonate of a codeine-prescribed mother which has been afterward classified as an ultra-rapid metaboliser for CYP2D6 polymorphism: since the frequency of CYP2D6 ultra-rapid metaboliser genotypes ranges from $1 \%$ in Finland and Denmark to $10 \%$ in Greece and Portugal, and 29\% in Ethiopia, this polymorphism is clinically relevant [6]. CYP2D6 polymorphisms are clinically significant also for atomoxetine treatment, which has been approved in 2002 for the treatment of attention deficit hyperactivity disorder (ADHD) in children, adolescents and adults, in addition to methylphenidate (MPH), the most commonly prescribed psycho-stimulant in ADHD affected 
children, as described later in this review. CYP2D6 genotyping may be beneficial in preventing overdosing and subsequent ADRs or early cessation. Moreover, recently it has been demonstrated that recognizing intermediate metabolizers is clinically important, because these children receive tailored therapeutic advice based on their genotype [7].

While it is known the effect of genetic variations in drug metabolism, much less attention has been given to developmental pharmacogenomics. Some genes are expressed much more in early life than in adults. One of the best example of gene switching is represented by CYP3 gene family: CYP3A7 expression level is detectable as early as 50 to 60 days gestation in fetal liver, and its expression begins to decline after the first postnatal week, reaching non-detectable levels in most individuals by 1 year of age. Simultaneously, hepatic CYP3A4/ 3A5 expression begins to dramatically increase at about 1 week of age, reaching $30 \%$ of adult levels by 1 month. So, total CYP3A protein expression over the entire developmental period remains constant. However, because CYP3A7 and CYP3A4 exhibit differences in substrate specificity and catalytic efficacy, some differences in metabolic capacity during development are observed [8]. If is true that many genes are expressed much more in early life than in adults, is also true that many drug metabolizing enzymes (DME) are less developed in children than in adults. An example is the UDP glucuronosyltransferase (UGT), which is a liver enzyme essential for body's elimination of xenobiotic substances as well as endogenous substances including endogenous toxins and bilirubin. Only $1 \%$ of the normal adult level of hepatic bilirubin-UGT activity is present at birth [9]. Postnatal maturation of bilirubin-UGT is birth related, and increases rapidly to adult levels by 14 weeks, regardless of the gestational age at birth [10], maybe in relation to the methylation or acetylation status of this locus.

The application of pharmacogenetic and pharmacogenomic approaches to the treatment of pediatric diseases requires an appreciation of these dynamic changes in gene expression. It is assumed that drug effects differ in children but in reality this perception often arises because the drugs have not been adequately studied in pediatric populations of different ages and with different diseases [11]. Moreover, part of the reason for the perception that pharmacodynamics are different in children is because the pharmacokinetics may be different at different ages. However, advances in this field have been hampered by several problems. Most reports on the developmental expression of DMEs have limited their studies to short time frames of development, many have depended on a small number of tissue samples, mostly confined to the hepatic expression during fetal development. Furtherome, there is also a paucity of information regarding changes during early childhood or at puberty [8]. While the pharmacogenetics as the study or clinical testing of genetic variation that gives rise to differing response to drugs might be considered similar in adults 
and children, the 'pharmacogenomics' as the study of how interacting systems of genes determine drug response [12] is particularly appealing in a pediatric and developmental context because this definition captures the essence of the developmental processes that characterize maturation from the time of birth through to adulthood [5]. 


\section{Methods for Pharmacogenetics and Pharmacogenomics Studies}

In this section, we consider recent genetic and genomic strategies for identifying genetic and genomics variations that influence the response to particular treatments or therapies. We describe common methodological approaches that can be applied to pharmacogenetics and pharmacogenomics studies for both children and adults.

\section{Case-Control Association Studies: From Candidate Genes to Genome-wide Screen}

One of the most common study designs used to assess pharmacogenetic effects is that of the case-control association study. In the context of pharmacogenetics, the usual approach is to examine the active treatment arm of a clinical trial and divide subjects in the treatment arm into those with a positive response to the drug and those with a negative or no response. These two groups then constitute cases and controls who are genotyped for a particular candidate gene thought to be related to the treatment phenotype.

The problem with such studies is that, though they are easy to perform, they are fraught with a host of potential biases or difficulties in interpretation. Four design issues must be considered in any genetic case-control association study.

1. The major problem in case control studies is ensuring a good match between the genetic background of cases and controls, so that any genetic difference between them is related to the disease under study and not to biased sampling. Clearly, cases and controls should be from similar ethnic groups. More subtle genetic differences can be guarded against by collecting controls from the same geographical area as cases, or by collecting information such as the birth place of grandparents to check a similar distribution between cases and controls. Matching of cases and controls for ethnicity or use of multiple unlinked markers to assess for the presence of this confounding variable are useful techniques to detect or eliminate the potential bias of population stratification [13].

2. The key determinant of quality in an association study is sample size. With the remote chance of finding common genes with large effects, studies must be powered to detect variants that are common - but have low relative risk - or rarer - but with higher relative risk - which means samples sizes of thousands. Rare variants with low relative risks are largely beyond the reach of genetic epidemiology because of the massive sample size that would be needed [14].

3. An additional criterion for evaluation of the quality of the case-control study is assessment of Hardy-Weinberg equilibrium in the markers studied within the control group. Hardy-Weinberg equilibrium implies that the genotype frequencies can be determined directly from the allele 
frequencies and provides a check to ensure that genotyping errors, mutation, or population stratification do not explain observed results.

4. The final key to these studies is replication, which can be performed with a second case-control association study or a family-based study. Replication performed with family-based designs can be used in conjunction with a case-control association study.

Careful attention to these four issues that we have highlighted would go a long way to improving the quality of existing studies and preventing false positive associations. However, we would like also to notice that other issues can be addressed in any case-control association study such as: selection of candidate gene polymorphism (bioinformatic tools), observation bias (phenotyping and genotyping methods), linkage disequilibrium, allele or genotyped analysis, multivariate analysis, gene-gene and gene-environment interaction, correction for multiple comparisons.

The availability of very high throughput DNA analysis technologies (like single nucleotide polymorphism (SNP) array) and the development of databases (HapMap project) harboring information about the genomic positions of DNA sequence variations have provided geneticists with efficient and powerful tools for identifying inherited DNA sequence variations that contribute to phenotypic expression and variability. In fact, it is now possible to test literally hundreds of thousands, if not a million or so, polymorphic markers for association with a particular phenotype in a single study. This kind of study focus on as many variations as possible in the absence of such a priori knowledge is named genome-wide association study (GWAS).

Each study can look at hundreds or thousands of SNPs at the same time. Researchers use data from this type of study to pinpoint genes that may contribute to a person's risk of developing a certain disease. Because GWASs examine SNPs across the genome, they represent a promising way to study complex, common diseases in which many genetic variations contribute to a person's risk. This approach has already identified SNPs related to several complex conditions including diabetes, heart abnormalities, Parkinson disease, and Crohn disease. A few of GWAS have been performed to discovery SNPs involved in drug therapy. Results of the 12 pharmacogenomics GWASs published so far are summarized in a recent review by Crowley et al. [15], as well as in the NHGRI GWAS catalog [16]. Six GWASs evaluated the association of genetic variation with drug efficacy, five evaluated adverse effects, and one examined a dose-response relationship (warfarin) [17].

GWASs have been recognized as an important approach for uncovering polymorphisms accounting for individual differences in drug efficacy and drug safety [18]. A vast reservoir of observational studies and randomized clinical trials (RCTs) - completed, ongoing or planned provides a largely untapped resource for pharmacogenomic studies of drug safety and efficacy. In 
particular, RCTs allow for precise measurement of drug exposure and consistent ascertainment of phenotype; randomization produces unbiased treatment assignments and helps balance unmeasured confounding factors [19]. Performing GWASs within clinical trials, in which more potentially interacting variables can be identified, measured and controlled, improves efficiency. So far, only two GWASs have been conducted in drug clinical trials; each of these studies provides relevant insights for future research. Given their efficiency and potential for leading to useful clinical medicine and public health applications, it seems surprising that so few GWASs have been done in the field of pharmacogenomics, especially within clinical trials. The incentives for conducting such studies deserve closer evaluation, especially for the studies of childhood-disease treatment response. 


\section{Pharmacogenetics studies in childhood conditions}

Genetic diversity is a consequence of differences in DNA sequences. There are multiple types of genetic variation including SNPs, copy-number variations (CNVs), variable number of tandem repeats (VNTR), microsatellite polymorphisms, and cytogenetic rearrangements. There are a lot of scientific evidences that show how genetic variation can determine impaired response to drugs (Table 1). Here we present an overview of pharmacogenetic studies of the most common childhood conditions, such as attention-deficit/hyperactivity disorder (ADHD), growth hormone deficiency (GHD), Acute lymphoblastic leukemia (ALL) and asthma.

\section{Attention-deficit/hyperactivity disorder}

Attention-deficit/hyperactivity disorder (ADHD) is a multifactorial disorder characterized by physical hyperactivity and behavioural disinhibition that typically emerges during childhood or adolescence and often persists into adulthood. It was estimated approximately $70 \%$ of response rate to methylphenidate (MPH), the most commonly prescribed psycho-stimulant, in ADHD affected children $[20,21]$. Pharmacogenetic studies suggest that inter-individual differences in stimulantresponse may be related to genetic influences [22-29]. The search for candidate genes associated with ADHD has been largely driven by the understanding that medications for the disorder have drug targets in the catecholamine system. Genes associated with increased risk for ADHD are the dopamine transporter (DAT1) [25], the dopamine receptors (DRD4 and DRD5) [30], serotonin transporter (5-HTT), and synaptosomal-associated protein (SNAP-25) [31-33]. Other genes of potential interest in pharmacogenetic studies of ADHD include catehol-O-methyltransferase (COMT) [26], the adrenergic $\alpha 2$-receptor (ADRA2A and ADRA1A) [27, 34, 35] (Table 1). However, some pharmacogenetic studies show conflicting results. For example, in some of them individuals homozygous for the DAT1 10-repeat 480 bp-VNTR showed poorer outcome [23, 24], whereas others report improved clinical outcome [28] or no effect [29] on MPH response.

\section{Growth hormone deficiency}

GH replacement is standard therapy for children with short stature due to GH deficiency (GHD). The usual treatment is carried out with fixed doses of human recombinant GH (hGH) adjusted for body weight or surface [36]. Two of the most common isoforms of GHR in humans are generated by retention (full-length GHR, GHRfl) or exclusion of exon 3 (exon 3-deleted GHR, GHRd3) [37]. These isoforms present a widespread distribution in humans, with the frequency of each allele ranging from $68-75 \%$ for GHRfl and $25-32 \%$ for GHRd3 [37, 38]. In 2004, in a study 
conducted on two cohorts of 76 and 96 children of European descent with idiopathic short stature or who were born small for gestational age, it has been demonstrated that, patients with at least one GHRd3 allele presented 1.7 to 2 times more growth acceleration induced by hGH therapy than patients homozygous for the full-length isoform [38]. These observations have been confirmed in some but not all studies, so it remains unclear at this time as to whether the d3-GHR isoforms actually conveys increased GH responsiveness. It will require a large-scale, prospective, wellcontrolled study, with appropriate assessment of proteomic and genomic markers of GH action, as well as auxological data, to settle this issue. Nevertheless, this study served to open the door to the potential importance of genomic and proteomic biomarkers as indicators and predictors of GH responsiveness [39]. Another study, conducted by Jorge and colleagues, is a good example of a direct relation between genetic variability and adult height after long-term treatment with hGH, since there are only few data in literature about long-term effects of drugs. They demonstrated that patients carrying at least one GHRd3 allele had a significantly better growth velocity in the first year of hGH replacement and achieved a taller adult height when compared with patients homozygous for GHRfl alleles [36].

\section{Acute lymphoblastic leukemia}

The therapeutic class that could benefit more from PGt and PGx is cancer chemotherapy. Anticancer agents are often given at doses near those that produce toxicity, show wide inter-patient variability in disposition and effects, and should be given at optimal doses for the best chance of cure. Cancer is the leading cause of death by disease in children between 1 and 15 years of age in the USA, with leukemia continuing to cause the highest proportion (33\%) of these deaths [40]. ALL accounts for about $25 \%$ of all cancers in children. Despite the significant progress in treatment of ALL, long-term event-free survival rates are currently almost $80 \%$, with $20 \%$ of patients who do not respond to standard therapy [31]. Treatment response can be altered by polymorphisms in genes encoding enzymes that metabolize chemotherapeutic agents. The thiopurine methyltransferase (TPMT) genetic polymorphisms and mercaptopurine toxicity are one of the best-studied examples in pharmacogenetics. Although 23 variant alleles have been identified to date [41], 3 variant alleles (TPMT*2 [Ala80Pro], TPMT*3A [Ala154Thr and Tyr240Cys] and TPMT*3C [Tyr240Cys]) account for $>95 \%$ of low or intermediate TPMT enzyme activity: patients with TPMT deficiency are at very high risk of severe hematopoietic toxicity if treated with conventional doses of thiopurines [40, 42, 43]. Patients who are heterozygous at the TPMT locus are at intermediate risk of dose-limiting toxicity and might require a modest dose reduction of approximately 35-50\%, whereas TPMT-deficient patients require a dose reduction of $>90 \%$ [40]. Other important genes 
involved in ALL therapy are those codifying for the enzymes of the glutathione-S-transferase (GST) family. The polymorphisms of these genes have been associated with increased cancer incidence, therapy-related cancers and toxicity following chemotherapy [40, 44]. Polymorphisms of GSTM1, GSTP1, and GSTT1 exist in all populations. The GSTM1*0 (GSTM1 null) and GSTT1*0 (GSTT1 null) alleles represent deletions of GSTM1 and GSTT1 genes respectively and result in a loss of enzymatic activity [45]. The $1578 \mathrm{~A}>\mathrm{G}$ transition in GSTP1 gives rise to the Ile105Val polymorphism, which confers reduced enzyme activity [46]; it is associated with high etoposide clearance in African-Americans treated with steroids [47]. Methotrexate (MTX) is also an important chemotherapeutic drug in the treatment of ALL. Methylenetetrahydrofolate reductase (MTHFR) is an essential enzyme in the folate/methotrexate metabolism pathway. About $10 \%$ of Caucasians show a genotypic variant of MTHFR (677 C > T; Ala222Val), which encodes a protein with about $30 \%$ of the wild-type activity [48]. This SNP has been linked to hepatotoxicity following methotrexate treatment [49]. Another low-function variant of MTHFR results from the $1298 \mathrm{~A}>\mathrm{C}$ (Glu429Ala) substitution; it has been reported to be protective for adult acute lymphocytic leukemia $[50,51]$ but not to altered effects of MTX in leukaemia [52] (Table 1).

\section{Asthma}

Asthma is the most common chronic disease among children. In 2002, >30 million US individuals reported having been diagnosed as having asthma, including 122 per 1000 children [53]. Agonists of $\beta 2$ adrenergic receptor (ADRB2) are the most widely used drug in the treatment of asthma: it has been demonstrated that a common polymorphism in the coding region of ADRB2 gene influences the response to shortacting albuterol therapy in children with asthma (Table 1). Bleecker and colleagues have recently tested the drug response effect of ADRB2 coding polymorphism in two randomised studies, the first conducted on 2250 asthmatics, the second on 405. The results of this important study showed no pharmacogenetics affect of this genetic variant on therapeutic response when the patients were treated with inhaled corticosteroids plus longacting $\beta 2$-agonists [54]. However this one of the few examples of PGt application in clinical trials in childhood (the participants aged 12 years or more) and mainly emphasizes the problem of small sample sizes in case control association studies that leads to false-positive or false-negative findings.

The other two modality of asthma treatment are corticosteroids and leukotriene modifiers, and polymorphisms of the genes (CRHR1, LTC4, ALOX5) involved in their modulation have been described (Table 1). However, also on this field contradictory results have been reported. For 
example, the LTC4S $-444 \mathrm{~A}>\mathrm{C}$ promoter polymorphism has been associated to a reduced risk for asthma exacerbations when compared with individuals homozygous for reference allele [55, 56, $31]$; in other studies this observation was not consistent $[57,58]$ (Table 1). 


\section{The omics world: current state and future perspectives}

\section{Implication and importance of miR-polymorphisms in Pharmacogenomics}

MicroRNAs (miRNA) are small, single-stranded, 21-23 nucleotide-long, independent functional units of noncoding RNA [59-61]. Often referred to as the "micromanagers of gene expression", miRNAs are evolutionarily well-conserved and, by binding to the target transcript in the 3'-UTR, can inhibit the translation of proteins and destabilize their target mRNA $[62,63]$.

Pharmacogenomics of miRNA is a novel and promising field of research that holds new possibilities for tailor-made medical therapy. MiRNA pharmacogenomics can be defined as the study of miRNAs and polymorphisms affecting miRNA function in order to predict drug behavior and to improve drug efficiency $[64,65]$. MiRNA pharmacogenomics has strong clinical implications for several reasons: miRNAs are attractive drug targets, are differentially expressed in malignant versus normal cells and regulate expression of several important proteins in the cell [6668]. MiR-polymorphisms can interfere with miRNA function resulting in loss of the miRNAmediated regulation of a drug-target gene conferring drug resistance [62]. Therefore, these miRpolymorphisms have potential as predictors of drug response in the clinic and will result in development of more accurate methods of determining appropriate drug dosage based on a patient's genetic makeup, thus decreasing the likelihood of drug overdose [65].

Transcriptomics, Metabonomics and Proteomics: other research areas completing Pharmacogenetics and Pharmacogenomics

Transcriptomics [69] refers to the study of gene transcripts, generally analyzed by cDNA expression microarrays. Such cDNA expression studies have led to a number of exciting breakthroughs in basic science. For example, microarray analysis of certain tumors has been successful in correlating a particular microchip pattern with a patient's prognosis [70]. Recent works indicate that global gene-expression profiling using DNA microarrays can identify genes with levels of expression that are related to drug response. An advantage of this strategy is that it includes all genes of potential importance and, therefore, might identify new therapeutic and diagnostic targets. Its disadvantage is that, as a non-targeted genome-wide approach, it is influenced by 'noise' (that is, expression signals of irrelevant genes) and increases the number of false positives (that is, unimportant genes that are identified by chance). Identification of genes on the basis of mRNA expression relative to drug response is complementary to the identification of SNPs in genes that alter protein function and drug response. Moreover, this might lead to the identification of SNPs that are associated with altered mRNA expression of genes associated with 
drug response. Acute lymphoblastic leukemia (ALL) is an ideal model system in which to assess global gene expression in cancer, because it is a 'liquid' tumour and therefore relatively homogeneous within a patient, and because it is easy to isolate and characterize. Robust geneexpression profiling for diagnosis and classification of childhood ALL might ultimately represent a less labour-intensive and more automated alternative to the multiple methods that are currently used (for example, immunochemistry, cytogenetics and molecular diagnostics) [71-75]. Studies of leukaemia-cell gene-expression patterns might also reveal new prognostic features and therapeutic targets. For instance, gene profiles might ultimately be able to identify children for whom therapy is likely to fail (that is, those who will experience relapse) or those who are at high risk of therapyinduced second cancers [76-79].

The major limitation of microarray studies is the availability of the appropriate source of sampling-blood or excreta (urine, saliva, sweat, breast milk, ejaculate, menses, feces) or tissue in which relevant cDNAs or proteins exist (dissected tumor, tissue biopsies, placenta, foreskin). It would be unethical and unreasonable to attempt to predict individual drug response outcomes from biopsies of liver, lung, kidney or brain in healthy patients.

Metabonomics (also called "metabolomics") refers to the study of metabolite profiling [80, 81]. Although this field is similarly limited by the same sampling problems as transcriptomics, there is an important difference. The metabonome represents an integrated (systems biology) response, in real time, to all endogenous plus all exogenous stimuli (drugs, chemical exposures, occupation, lifestyle, nutrition, age, gender). Metabonomics thus might provide an exquisitely sensitive means to follow an individual patient's phenotype, as a function of age, nutrition, course of disease, or therapy. Accordingly, in principle, this technique offers great promise in personalized drug therapy and medicine, but may also be subject to some of the pitfalls identified above for pharmacogenomics.

Metabonomics might therefore be considered analogous to a "liver profile" test in clinical pathology, except that metabonomics includes measurement of metabolites present at much lower concentrations and, accordingly, provides several orders of magnitude greater sensitivity (femtomolar to attomolar range). Even though metabolite profiling can be performed only on easily available samples - such as blood, urine or other excreta, dissected tumor, or biopsy tissues - this method still holds promise of clinical success, and might be regarded as an extension of the present practice of clinical pharmacology [82]. It seems practicable that, in the more distant future, metabonomics will help genomics to revolutionize and individualize drug therapy. 
Proteomics, the study of all proteins encoded by the genome [83], has also been successful in certain areas of basic research. Although a recent study [84] estimated an average of 3.0 human proteins per gene, others have estimated that the true number of proteins per gene might be considerably higher. Proteomics - like transcriptomics and metabolomics - suffers from the types of source that must be sampled, e.g., blood, excreta or biopsy or tumor tissue in which relevant proteins exist. It is conceivable however that in the future proteomics investigators might identify certain protein profiles, similar to ways in which metabonomics can identify certain metabolite profiles, which might be useful for predicting adverse drug reactions long before they become overt. We expect to see during the next several years a successful complementation of genetics and genomics by both metabonomics and proteomics. Particularly, when the population understudy is composed of children as their drug response capability may be different at different ages. 


\section{Conclusions}

Pharmacogenetics and pharmacogenomics hold out the promise of helping to achieve the goal of individualized drug therapy. Their translation into the clinic has been relatively slow both for the adulthood diseases as well as for the childhood diseases. Often pharmacogenetics and pharmacogenomics studies show contradictory results, that reflect inconsistent research methods, small sample sizes, no replication study, no standardized outcome measures, or little consideration of potential covariates such as co-morbidity. Before pharmacogenomic testing can be effectively utilized clinically, more data are necessary from randomized controlled clinical trials to determine the efficacy and clinical utility. Nevertheless, there is no estimate of what and how much genetic variations in gene products involved in drug disposition are useful in clinical practice and there are only few data on long-term adverse effects of drugs. We expect that future approaches will use also large-scale public genetic databases such us the HapMap project to elucidate linkage of genetic markers and drug effects in different populations, towards the identification of new genes and the elucidation of polygenic determinants of drug responses.

We also would like to underline that children should not be considered as small adults when we approach to a pharmacogenetic or pharmacogenomic studies. Children present differences arising from the various stages of development. Many patterns of ontological development in the systems of the body illustrate how paediatric patients can differ from adults. Genotypes do not always correspond with expected phenotypes, making the job of deciding how to treat childhood disease and apply genomic research to paediatric medicine all the more complex. The scientific and lay communities should work diligently and creatively to design research appropriate for pediatric populations. For instance, we expect to see during the next years a complementation of genetics and genomics by both metabonomics and proteomics. The impacts of pharmacogenetic and pharmacogenomic research already stand to greatly enhance the safety of treating children diagnosed with ALL, as TPMT-deficient individuals can be easily identified. Pharmacogenetic and pharmacogenomic study should be continually applied to pediatric populations in an effort to provide for children the equity and hope for progress in treatment, discovery and understanding of disease already present in adult populations. 


\section{ACKNOWLEDGEMENTS}

This work was supported by grants from Regione Campania (DGRC 2362/07) and from MIUR (PS 35-126/Ind). Mario Capasso was supported by Associazione Oncologia Pediatrica e Neuroblastoma (OPEN).

This contribution is part of the Task-force in Europe for Drug Development for the Young (TEDDY) Network of Excellence supported by the European Commission's Sixth Framework Program (Contract n. 0005216 LSHBCT- 2005-005126) 


\section{References}

1. Kirchheiner J, Nickchen K, Bauer M, Wong ML, Licinio J, Roots I, Brockmöller J (2004) Pharmacogenetics of antidepressants and antipsychotics: the contribution of allelic variations to the phenotype of drug response. Mol Psychiatry 9: 442-473

2. Stanulla M, Schaeffeler E, Flohr T, Cario G et al (2005) Thiopurine methyltransferase (TPMT) genotype and early treatment response to mercaptopurine in childhood acute lymphoblastic leukemia. JAMA 293: 1485-1489

3. Phillips KA, Veenstra DL, Oren E, Lee JK, Sadee W (2001) Potential role of pharmacogenomics in reducing adverse drug reactions: a systematic review. JAMA 286: 2270-2279

4. Krekels EH, van den Anker JN, Baiardi P, Cella M et al (2007) Pharmacogenetics and paediatric drug development: issues and consequences to labelling and dosing recommendations. Expert Opin Pharmacother 8: 1787-99

5. J.S. Leeder (2003) Developmental and pediatric pharmacogenomics. Pharmacogenomics 4: $331-341$

6. G. Koren, J. Cairns, D. Chitayat, A. Geadigk, S. Leeder. Pharmacogenetics of morphine poisoning in a breastfed neonate of codeine-prescribed mother. Lancet, 368

7. ter Laak MA, Temmink AH, Koeken A, van 't Veer NE, van Hattum PR, Cobbaert CM (2010) Recognition of impaired atomoxetine metabolism because of low CYP2D6 activity. Pediatr Neurol 43: 159-162

8. Hines RN, McCarver DG (2002) The ontogeny of human drug-metabolizing enzymes: phase I oxidative enzymes. J Pharmacol Exp Ther 300: 355-360

9. Odell GB (1967) "Physiologic" hyperbilirubinemia in the neonatal period. N Engl J Med 277:193-195

10. Kawade N, Onishi S (1981) The prenatal and postnatal development of UDPglucuronyltransferase activity towards bilirubin and the effect of premature birth on this activity in the human liver. Biochem J 196:257-260

11. Stephenson T (2005) How children's response to drugs differ from adults. Br J Clin Pharmacol 59: 670-673

12. Klein TE, Chang JT, Cho MK, Easton KL et al (2001) Integrating genotype and phenotype information: an overview of the PharmGKB project. Pharmacogenomics J 1: 167-170

13. Pritchard JK, Rosenberg NA (1999) Use of unlinked genetic markers to detect population stratification in association studies. Am J Hum Genet 65: 220-228 
14. Campbell MJ, Julious SA, Altman DG (1995) Estimating sample sizes for binary, ordered categorical, and continuous outcomes in two group comparisons BMJ 311: 1145-1148

15. Crowley JJ, Sullivan PF, McLeod HL (2009) Pharmacogenomic genome-wide association studies: lessons learned thus far. Pharmacogenomics 10: 161-163

16. National Human Genome Research Institute (NHGRI) GWAS catalog [http://www.genome.gov/26525384]

17. HuGE Navigator [http://hugenavigator.net/]

18. Gurwitz D, McLeod HL (2009) Genome-wide association studies: powerful tools for improving drug safety and efficacy. Pharmacogenomics 10: 157-159

19. Maitland ML, Ratain MJ, Cox NJ (2007) Interpreting P values in pharmacogenetic studies: a call for process and perspective. J Clin Oncol 25: 4513-4515

20. Elia J, Borcherding B, Rapoport J, Keysor C (1991) Methylphenidate and dextroamphetamine treatments of hyperactivity: are there true nonresponders? Psychiat Res 36: $141-155$

21. Spencer T, Biederman J, Wilens T, Harding M, O’Donnell D, Griffin S (1996) Pharmacotherapy of attention-deficit/hyperactivity disorder across the lifespan. J Am Acad Child Adolesc Psychiatry 35: 409-428

22. Gilbert DL, Wang Z, Sallee FR et al (2006) Dopamine transporter genotype influences the physiological response to medication in ADHD. Brain 129: 2038-2046

23. Winsberg BG, Comings DE (1999) Association of the dopamine transporter gene (DAT1) with poor methylphenidate response. J Am Acad Child Adolesc Psychiatry 38: 1474-1477

24. Roman T, Szobot C, Martins S, Biederman J, Rohde LA, Hutz MH (2002) Dopamine transporter gene and response to methylphenidate in attention-deficit/hyperactivity disorder. Pharmacogenetics 12: 497-499

25. Purper-Ouakil D, Wohl M, Orejarena S, Cortese S et al (2008) Pharmacogenetics of Methylphenidate Response in Attention Deficit/Hyperactivity Disorder: Association With the Dopamine Transporter Gene (SLC6A3). Am J Med Genet B Neuropsychiatr Genet 147B: $1425-1430$

26. Kereszturi E, Tarnok Z, Bognar E et al (2008) Catechol-O-Methyltransferase Val158Met Polymorphism Is Associated With Methylphenidate Response in ADHD Children. Am J Med Genet B Neuropsychiatr Genet 147B: 1431-1435

27. TL da Silva, Pianca TG, Roman T et al (2008) Adrenergic a2A receptor gene and response to methylphenidate in attention-deficit/hyperactivity disorder-predominantly inattentive type. J Neural Transm 115: 341-345 
28. Kirley A, Lowe N, Hawi A, Mullins C, Daly G, Waldman I et al (2003) Association of the 480bp DAT1 allele with methylphenidate response in a sample of irish children with ADHD. Am J Med Genet 121B: 50-54

29. Langley K, Turic D, Peirce TR, Mills S, van den Bree MB, Owen MJ et al (2005) No support for association between the dopamine transporter (DAT 1) gene and ADHD. Am J Med Genet B Neuropsychiatr Genet 139: 7-10

30. Van Tol HH, Wu CM, Guan HC, Ohara K, Bunzow JR, Civelli O, Kennedy J, Seeman P, Niznik HB, Jovanovic V (1992) Multiple dopamine D4 receptor variants in the human population. Nature 358: 149-52

31. Husain A, Loehle JA and Hein DW (2007) Clinical pharmacogenetics in pediatric patients. Phramacogenomics 8: 1403-1411

32. Faraone SV, Perlis R, Doyle AE, Smoller JW, Goralnick JJ, Homgren MA, et al (2005) Molecular genetics of attention-deficit/hyperactivity disorder. Biol Psychiatry 57: 13131323

33. McGough J, McCracken J, Swanson J et al (2006) Pharmacogenetics of methylphenidate response in preschoolers with ADHD. J Am Acad Child Adolesc Psychiatry 45: 1314-1322

34. Polanczyk G, Zeni C, Genro J, et al (2007) Association of the adrenergic alpha2A receptor gene with methylphenidate improvement of inattentive symptoms in children and adolescents with attention-deficit/hyperactivity disorder. Arch Gen Psychiatry 64: 218-224

35. Elia J, Capasso M, Zaheer Z, Lantieri F, Ambrosini P, Berrettini W, Devoto M, Hakonarson $\mathrm{H}$ (2009) Candidate gene analysis in an on-going genome-wide association study of attention-deficit hyperactivity disorder: suggestive association signals in ADRA1A. Psychiatr Genet 19: 134-41

36. Jorge AA, Marchisotti FG, Montenegro LR, Carvalho LR, Mendonca BB, Arnhold IJ (2006) Growth Hormone (GH) Pharmacogenetics: Influence of GH Receptor Exon 3 Retention or Deletion on First-Year Growth Response and Final Height in Patients with Severe GH Deficiency. J Clin Endocrinol Metab 91: 1076-1080

37. Pantel J, Machinis K, Sobrier ML, Duquesnoy P, Goossens M, Amselem S (2000) Speciesspecific alternative splice mimicry at the growth hormone receptor locus revealed by the lineage of retroelements during primate evolution. J Biol Chem 275: 18664-18669

38. Dos Santos C, Essioux L, Teinturier C, Tauber M, Goffin V, Bougneres P (2004) A common polymorphism of the growth hormone receptor is associated with increased responsiveness to growth hormone. Nat Genet 36: 720-724 
39. Rosenfeld RG (2007) Pharmacogenomics and pharmacoproteomics in the evaluation and management of short stature. Eur J Endocrinol 157: S27-S31

40. Cheok MH, Evans WE (2006) Acute lymphoblastic leukaemia: a model for the pharmacogenomics of cancer therapy. Nat Rev Cancer 6: 117-129

41. Ujiie S, Sasaki T, Mizugaki M, Ishikawa M, Hiratsuka M (2008) Functional characterization of 23 allelic variants of thiopurine S-methyltransferase gene (TPMT*2 - *24). Pharmacogenet Genomics 18: 887-93

42. Lennard L, Lilleyman JS, Van LJ, Weinshilboum RM (1990) Genetic variation in response to 6-mercaptopurine for childhood acute lymphoblastic leukaemia. Lancet 336: 225-229

43. Yates CR, Krynetski EY, Loennechen T, Fessing MY et al (1997) Molecular diagnosis of thiopurine S-methyltransferase deficiency: genetic basis for azathioprine and mercaptopurine intolerance. Ann Intern Med 126: 608-614

44. Hayes JD, Flanagan JU, Jowsey IR (2005) Glutathione transferases. Annu Rev Pharmacol Toxicol 45: 51-88

45. Rebbeck TR (1997) Molecular epidemiology of the human glutathione S-transferase genotypes GSTM1 and GSTT1 in cancer susceptibility. Cancer Epidemiol Biomarkers Prev 6: $733-7343$

46. Zheng Ye, Honglin Song (2005) Glutathione s-transferase polymorphisms (GSTM1, GSTP1 and GSTT1) and the risk of acute leukaemia: A systematic review and meta-analysis. Eur J Cancer 41: 980-989

47. Kishi S, Yang W, Boureau B, Morand S et al (2004) Effects of prednisone and genetic polymorphisms on etoposide disposition in children with acute lymphoblastic leukemia. Blood 103: 67-72

48. Frosst P, Blom HJ, Milos R, Goyette P et al (1995) A candidate genetic risk factor for vascular disease: a common mutation in methylene tetrahydrofolate reductase. Nature Genet 10: $111-113$

49. Ulrich CM, Yasui Y, Storb R, Schubert MM, Wagner JL, Bigler J, Ariail KS, Keener CL, Li S, Liu H, Farin FM, Potter JD (2001) Pharmacogenetics of methotrexate: toxicity among marrow transplantation patients varies with the methylenetetrahydrofolate reductase C677T polymorphism. Blood 98: 231-4

50. Skibola CF, Smith MT, Kane E, Roman E et al (1999) Polymorphisms in the methylenetetrahydrofolate reductase gene are associated with susceptibility to acute leukemia in adults. Proc Natl Acad Sci USA 96: 12810-12815 
51. Wiemels JL, Smith RN, Taylor GM, Eden OB et al (2001) Methylenetetrahydrofolate reductase (MTHFR) polymorphisms and risk of molecularly defined subtypes of childhood acute leukemia. Proc Natl Acad Sci USA 98: 4004-4009

52. Krajinovic M, Lemieux-Blanchard E, Chiasson S et al (2004) Role of polymorphisms in MTHFR and MTHFD1 genes in the outcome of childhood acute lymphoblastic leukemia. Pharmacogenomics J 4: 66-72

53. Mattke S, Martorell F, Sharma P, Malveaux F, Lurie N (2009) Quality of care for childhood asthma: estimating impact and implications. Pediatrics 123 Suppl 3: S199-204

54. Bleecker ER, Postma DS, Lawrance RM, Meyers DA, Ambrose HJ, Goldman M (2007) Effect of ADRB2 polymorphisms on response to longacting $\beta 2$-agonist therapy: a pharmacogenetic analysis of two randomised studies. Lancet 370: 2118-25

55. Sampson AP, Siddiqui S, Buchanan D, Howarth PH, Holgate ST, Holloway JW et al (2000) Variant LTC(4) synthase allele modifies cysteinyl leukotriene synthesis in eosinophils and predicts clinical response to zafirlukast. Thorax 55 Suppl 2: S28-31

56. Whelan GJ, Blake K, Kissoon N et al (2003) Effect of montelukast on time-course of exhaled nitric oxide in asthma: influence of LTC4 A(-444). Pediatric Pulmonol 36: 413-420

57. Currie GP, Lima JJ, Sylvester JE, Lee KD et al (2003) Leukotriene C4 synthase polymorphisms and responsiveness to leukotriene antagonistis in asthma. $\mathrm{Br} \mathrm{J}$ Clin Pharmacol 56: 422-426

58. Kedda MA, Shi J, Duffy D et al (2004) Characterization of two polymorphisms in the leukotriene $\mathrm{C} 4$ synthase gene in an Australian population of subjects with mild, moderate, and severe asthma. J Allergy Clin Immunol 113: 889-895

59. Lagos-Quintana M, Rauhut R, Lendeckel W, Tuschl T (2001) Identification of novel genes coding for small expressed RNAs. Science 294: 853-858

60. Lau NC, Lim LP, Weinstein EG, Bartel DP (2001) An abundant class of tiny RNAs with probable regulatory roles in Caenorhabditis elegans Science 294: 858-862.

61. Lee RC, Ambros V (2001) An extensive class of small RNAs in Caenorhabditis elegans. Science 294: 862-864

62. Mishra PJ, Humeniuk R, Mishra PJ, Longo-Sorbello GS, Banerjee D, Bertino JR (2007) A miR-24 microRNA binding-site polymorphism in dihydrofolate reductase gene leads to methotrexate resistance. Proc Natl Acad Sci U S A. 104: 13513-13518

63. Selbach M, Schwanhäusser B, Thierfelder N, Fang Z, Khanin R, Rajewsky N (2008) Widespread changes in protein synthesis induced by microRNAs. Nature 455: 58-63 
64. Mishra PJ, Mishra PJ, Banerjee D, Bertino JR (2008) MiRSNPs or MiR-polymorphisms, new players in microRNA mediated regulation of the cell: Introducing microRNA pharmacogenomics. Cell Cycle 7: 853-858

65. Mishra PJ, Bertino JR (2009) MicroRNA polymorphisms: the future of pharmacogenomics, molecular epidemiology and individualized medicine. Pharmacogenomics 10: 399-416

66. Calin GA, Dumitru CD, Shimizu M, Bichi R, Zupo S, Noch E, Aldler H, Rattan S, Keating M, Rai K, Rassenti L, Kipps T, Negrini M, Bullrich F, Croce CM (2002) Frequent deletions and down-regulation of micro- RNA genes miR15 and miR16 at 13q14 in chronic lymphocytic leukemia. Proc Natl Acad Sci U S A. 99: 15524-15529

67. Hon LS, Zhang Z (2007) The roles of binding site arrangement and combinatorial targeting in microRNA repression of gene expression. Genome Biol 8: R166

68. Iorio MV, Ferracin M, Liu CG, Veronese A, Spizzo R, Sabbioni S, Magri E, Pedriali M, Fabbri M, Campiglio M, Ménard S, Palazzo JP, Rosenberg A, Musiani P, Volinia S, Nenci I, Calin GA, Querzoli P, Negrini M, Croce CM (2005) MicroRNA gene expression deregulation in human breast cancer. Cancer Res 65: 7065-7070

69. Kiechle FL, Holland-Staley CA (2003) Genomics, transcriptomics, proteomics, and numbers. Arch Pathol Lab Med 127: 1089- 1097

70. McGregor PF (2003) Gene expression in cancer: the application of microarrays. Expert Rev Mol Diagn 3: 185- 200

71. Armstrong SA, Staunton JE, Silverman LB, Pieters R, den Boer ML, Minden MD, Sallan SE, Lander ES, Golub TR, Korsmeyer SJ (2002) MLL translocations specify a distinct gene expression profile that distinguishes a unique leukemia. Nature Genet 30: 41-47

72. Golub TR, Slonim DK, Tamayo P, Huard C, Gaasenbeek M, Mesirov JP, Coller H, Loh ML, Downing JR, Caligiuri MA, Bloomfield CD, Lander ES (1999) Molecular classification of cancer: class discovery and class prediction by gene expression monitoring. Science 286: 531-537

73. Ramaswamy S, Golub TR (2002) DNA microarrays in clinical oncology. J Clin Oncol 20: $1932-1941$

74. Moos PJ, Raetz EA, Carlson MA, Szabo A, Smith FE, Willman C, Wei Q, Hunger SP, Carroll WL (2002) Identification of gene expression profiles that segregate patients with childhood leukemia. Clin Cancer Res 8: 3118-3130

75. Ross ME, Mahfouz R, Onciu M, Liu HC, Zhou X et al (2004) Gene expression profiling of pediatric acute myelogenous leukemia. Blood 104: 3679-3687 
76. Ross ME, Zhou X, Song G, Shurtleff SA et al (2003) Classification of pediatric acute lymphoblastic leukemia by gene expression profiling. Blood 102: 2951-2959

77. Yeoh EJ, Ross ME, Shurtleff SA, Williams WK et al (2002) Classification, subtype discovery, and prediction of outcome in pediatric acute lymphoblastic leukemia by gene expression profiling. Cancer Cell 1: 133-143

78. Teuffel O, Dettling M, Cario G, Stanulla M, Schrappe M et al (2004) Gene expression profiles and risk stratification in childhood acute lymphoblastic leukemia. Haematologica 89: $801-808$

79. Willenbrock H, Juncker AS, Schmiegelow K, Knudsen S, Ryder LP (2004) Prediction of immunophenotype, treatment response, and relapse in childhood acute lymphoblastic leukemia using DNA microarrays. Leukemia 18: 1270-1277

80. Plumb, R.S., Stumpf, C.L., Gorenstein, M.V., Castro-Perez, J.M., Dear, G.J., Anthony, M., Sweatman, B.C., Connor, S.C., Haselden, J.N., 2002. Metabonomics: the use of electrospray mass spectrometry coupled to reversed-phase liquid chromatography shows potential for the screening of rat urine in drug development. Rapid Commun. Mass Spectrom. 16, 19911996.

81. Reo NV (2002) NMR-based metabolomics. Drug Chem Toxicol 25: 375- 382

82. Nebert DW, Jorge-Nebert LF, Vesell ES (2003) Pharmacogenomics and bindividualized drug therapyQ: high expectations and disappointing achievements. Am $J$ Pharmacogenomics 3: $361-370$

83. Campbell CJ, Ghazal P (2004) Molecular signatures for diagnosis of infection: application of microarray technology. J Appl Microbiol 96: 18-23

84. Xing Y, Resch R, Lee C (2004) The multi-assembly problem: reconstructing multiple transcript isoforms from EST fragment mixtures. Genome Res 14: 426- 441 
Table 1. Genetic polymorphisms in the most common childhood diseases

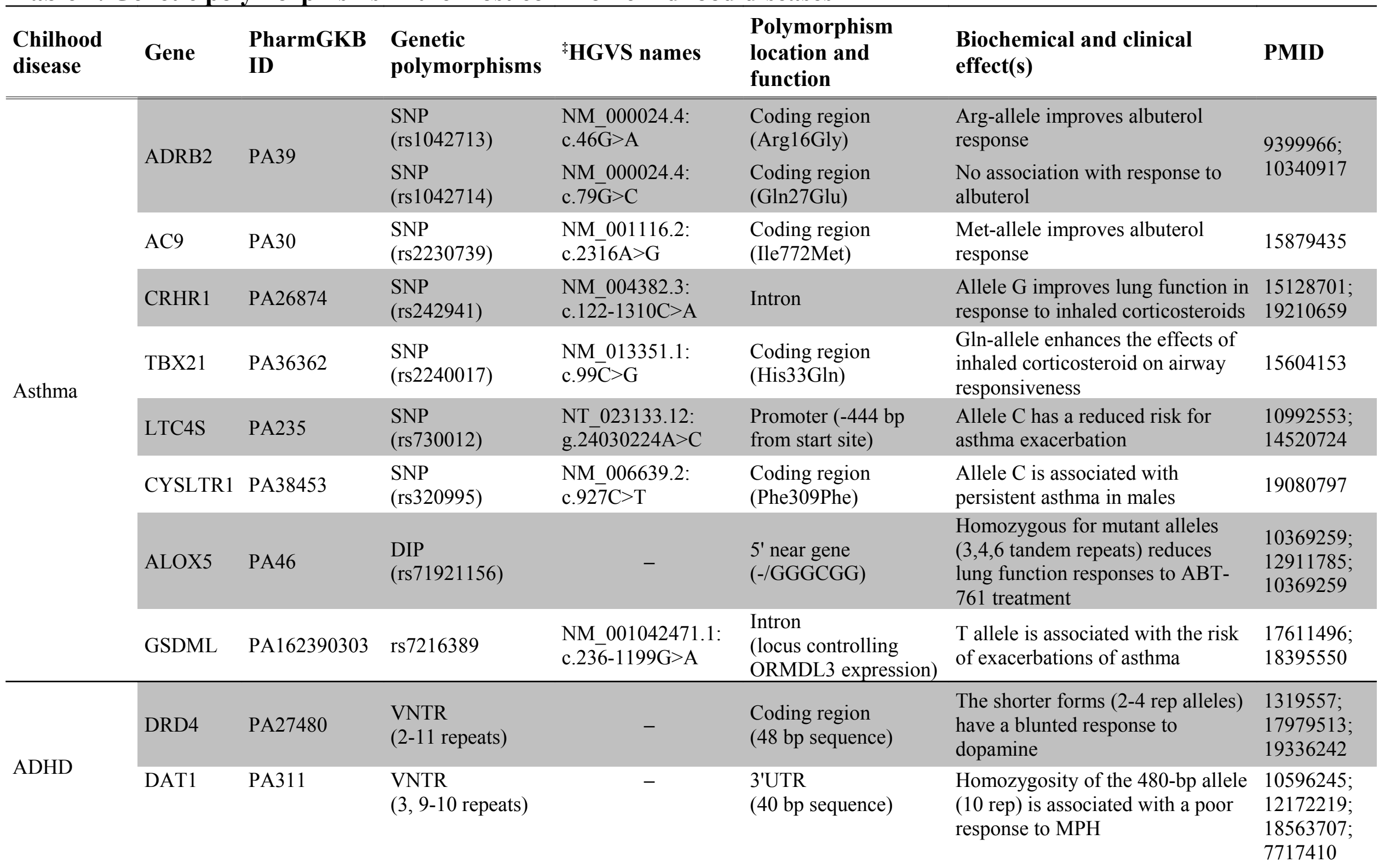




\begin{tabular}{|c|c|c|c|c|c|c|c|}
\hline & 5-HTT & PA312 & $\begin{array}{l}\text { DIP } \\
(\text { rs12720056) }\end{array}$ & - & $\begin{array}{l}\text { Promoter } \\
(-1212 \text { to }-1255)\end{array}$ & $\begin{array}{l}\text { The } 44 \text { bp deletion reduces } \\
\text { transcription and protein levels }\end{array}$ & $\begin{array}{l}11425009 \\
18200432 \\
8632190\end{array}$ \\
\hline & SNAP-25 & PA35980 & $\begin{array}{l}\text { SNP } \\
(\mathrm{rs} 3746544)\end{array}$ & $\begin{array}{l}\text { NM_003081.2: } \\
\text { c. }{ }^{*} 239 \mathrm{G}>\mathrm{T} \\
\mathrm{NM} 130811.1: \\
\text { c. }^{*} 239 \mathrm{G}>\mathrm{T}\end{array}$ & $\begin{array}{l}\text { 3'UTR } \\
\text { (Conserved element) }\end{array}$ & $\begin{array}{l}\text { Allele } \mathrm{T} \text { improves dose responses } \\
\text { in comparison with the allele } \mathrm{G}\end{array}$ & $\begin{array}{l}17979513 ; \\
15950004 ; \\
17023870\end{array}$ \\
\hline & $\mathrm{COMT}$ & PA117 & $\begin{array}{l}\text { SNP } \\
(\text { rs4680) }\end{array}$ & $\begin{array}{l}\text { NM 000754.2: } \\
\text { c. } 47 \overline{2} \mathrm{G}>\mathrm{A}\end{array}$ & $\begin{array}{l}\text { Coding region } \\
\text { (Val158Met) }\end{array}$ & $\begin{array}{l}\text { Val-allele or } \mathrm{Val} / \mathrm{Val} \text { genotype } \\
\text { have a good } \mathrm{MPH} \text { response }\end{array}$ & 18214865 \\
\hline & ADRA2A & PA35 & $\begin{array}{l}\text { SNP } \\
(\mathrm{rs} 1800544)\end{array}$ & $\begin{array}{l}\text { NT_030059.12: } \\
\text { g.31585029G }>C\end{array}$ & $\begin{array}{l}\text { Promoter }(-1291 \mathrm{bp} \\
\text { from start site; maps } \\
\text { to } \mathrm{CpG} \text { island })\end{array}$ & $\begin{array}{l}\text { Allele G improves effects of MPH } \\
\text { on inattentive symptoms after } 1 \\
\text { month of treatment }\end{array}$ & $\begin{array}{l}17283289 \\
18200436\end{array}$ \\
\hline \multirow[t]{6}{*}{ ALL } & TPMT & PA356 & $\begin{array}{l}\text { SNP } \\
\text { (rs1800462) } \\
\text { SNP } \\
(\text { rs } 1800460) \\
\text { SNP } \\
(\text { rs } 1142345)\end{array}$ & $\begin{array}{l}\text { NM_000367.2: } \\
\text { c. } 238 \mathrm{G}>\mathrm{C} \\
\mathrm{NM} 000367.2: \\
\text { c. } 460 \mathrm{G}>\mathrm{A} \\
\mathrm{NM} 000367.2: \\
\text { c. } 719 \mathrm{~A}>\mathrm{G}\end{array}$ & $\begin{array}{l}\text { Coding region } \\
\text { (Ala80Pro) } \\
\text { Coding region } \\
\text { (Ala154Thr) } \\
\text { Coding region } \\
\text { (Tyr240Cys) }\end{array}$ & $\begin{array}{l}\text { TPMT } * 2, \mathrm{TPMT}^{*} 3 \mathrm{~A} \text { and } \\
\text { TPMT*3C alleles have low or } \\
\text { intermediate TPMT enzyme } \\
\text { activity with high risk of severe } \\
\text { hematopoietic toxicity after } \\
\text { thiopurines treatment }\end{array}$ & $\begin{array}{l}1973780 \\
9103127 \\
16491071\end{array}$ \\
\hline & GSTT1 & PA183 & GSTT1 $1 * 0$ & - & Large deletion & Loss of enzymatic activity & $\begin{array}{l}8198545 \\
9298582\end{array}$ \\
\hline & GSTM1 & PA182 & GSTM1*0 & - & Large deletion & Loss of enzymatic activity & $\begin{array}{l}9298582 \\
9057653\end{array}$ \\
\hline & GSTP1 & PA29028 & $\begin{array}{l}\text { SNP } \\
(\mathrm{rs} 1695)\end{array}$ & $\begin{array}{l}\text { NM_000852.3: } \\
\text { c. } 313 \mathrm{~A}>\mathrm{G}\end{array}$ & $\begin{array}{l}\text { Coding region } \\
\text { (Ile105Val) }\end{array}$ & $\begin{array}{l}\text { Ile-allele confers high etoposide } \\
\text { clearance in African-Americans } \\
\text { treated with steroids }\end{array}$ & $\begin{array}{l}15862746 ; \\
12969965\end{array}$ \\
\hline & \multirow[t]{2}{*}{ MTHFR } & \multirow[t]{2}{*}{ PA245 } & $\begin{array}{l}\text { SNP } \\
(\mathrm{rs} 1801133)\end{array}$ & $\begin{array}{l}\text { NM_005957.3: } \\
\text { c. } 665 \mathrm{C}>\mathrm{T}\end{array}$ & $\begin{array}{l}\text { Coding region } \\
\text { (Ala222Val) }\end{array}$ & $\begin{array}{l}\text { Val-allele is a low-function variant } \\
\text { ( } 30 \% \text { of the wild-type activity). It } \\
\text { has a higher hepatotoxicity } \\
\text { following MTX treatment }\end{array}$ & \multirow[t]{2}{*}{$\begin{array}{l}7647779 ; \\
10536004 ; \\
11418485 ; \\
11274424\end{array}$} \\
\hline & & & $\begin{array}{l}\text { SNP } \\
(\text { rs } 1801131)\end{array}$ & $\begin{array}{l}\text { NM_005957.3: } \\
\text { c. } 1286 \mathrm{~A}>\mathrm{C}\end{array}$ & $\begin{array}{l}\text { Coding region } \\
\text { (Glu429Ala) }\end{array}$ & $\begin{array}{l}\text { Ala-allele is a lower-activity } \\
\text { variant. It not alters MTX effects }\end{array}$ & \\
\hline
\end{tabular}




\begin{tabular}{|c|c|c|c|c|c|c|c|}
\hline & GGH & PA432 & $\begin{array}{l}\text { SNP } \\
\text { (rs115450789) }\end{array}$ & $\begin{array}{l}\text { NM_003878.1: } \\
\text { c. } 452 \mathrm{C}>\mathrm{T}\end{array}$ & $\begin{array}{l}\text { Coding region } \\
\text { (Thr151Ile) }\end{array}$ & $\begin{array}{l}\text { Ile-allele is associated with } 67 \% \\
\text { lower catalytic activity in the } \\
\text { degradation of long-chain } \\
\text { MTXPG, but not short-chain }\end{array}$ & 16491071 \\
\hline \multirow{2}{*}{ GHD } & \multirow{2}{*}{ GHR } & \multirow{2}{*}{ PA28674 } & $\begin{array}{l}\text { GHRfl } \\
\text { (NM_000163) }\end{array}$ & - & Full lenght isoform & \multirow{2}{*}{$\begin{array}{l}\text { GHRd3 isoform had a better } \\
\text { growth velocity in the first year of } \\
\text { hGH replacement }\end{array}$} & \multirow{2}{*}{$\begin{array}{l}\text { 10764769; } \\
15208626 \\
16291702\end{array}$} \\
\hline & & & $\begin{array}{l}\text { GHRd3 } \\
\text { (AF210633) }\end{array}$ & - & $\begin{array}{l}\text { Exon 3-deleted } \\
\text { isofrom }\end{array}$ & & \\
\hline
\end{tabular}

ADHD, attention-deficit/hyperactivity disorder; ALL, acute lymphoblastic leukemia; GHD, growth hormone deficiency

SNP, single nucleotide polymorphism; DIP, deletion/insertion polymorphism; VNTR, variable number tandem repeat

MPH, methylphenidate; MTX, methotrexate; MTXPG, methotrexate polyglutamate

HGVS, Human Genetic Variation Society

PMID, PubMed Identifier 